\title{
The effect of combined pulsed radiofrequency treatment to dorsal root ganglion with transforaminal epidural steroid injection on pain
}

\author{
Transforaminal epidural steroid enjeksiyonu ile eş zamanlı dorsal kök ganglion üzerine \\ uygulanan darbeli radyofrekans tedavisinin ağrı üzerine palyatif etkisi
}

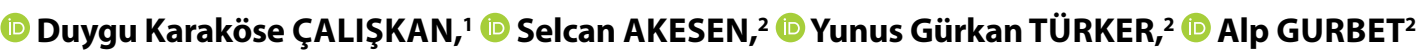

\begin{abstract}
Summary
Objectives: We aimed to compare the treatment response with simultaneous application of transforaminal epidural steroid injection (TESI) and pulsed radiofrequency (PRF) to the lumbar dorsal root ganglion (DRG) with TESI in patients with chronic lumbar radicular pain.

Methods: A total of 129 patients were enrolled. TESI was performed to 67 patients and TESI+DRG-PRF was performed to 62 patients. Demographic data, surgical records, and medications, side, and level of the procedure were recorded. Patients were evaluated on the pre-operative and post-operative $10^{\text {th }}$ day, $1^{\text {st }}$ and $3^{\text {rd }}$ month follow-up visits, and visual analog scale (VAS, $0-10)$ scores, and patients' satisfaction assessment on the $3^{\text {rd }}$ month follow-up were collected. A successful therapeutic response was defined as a $50 \%$ or more reduction in VAS scores.

Results: In both groups, post-operative VAS scores were significantly lower than the pre-operative levels $(p<0.001)$. VAS scores in the TESI+DRG-PRF group were significantly lower than the TESI group at all follow-up periods $(p<0.001)$. Reduction ratios in VAS scores were significantly higher in the TESI+DRG-PRF group in all follow-up visits $(p<-0.001)$. Satisfaction levels were significantly higher in the TESI+DRG-PRF group $(p<0.01)$.

Conclusion: According to our study, TESI provides short-moderate pain relief in patients with chronic lumbar radicular pain. A simultaneous application of PRF in the same session with TESI should be considered as an option to improve the treatment response.
\end{abstract}

Keywords: Dorsal root ganglion; lumbar radicular pain; pulsed radiofrequency; transforaminal epidural steroid injection.

\begin{abstract}
Özet
Amaç: Kronik lomber radiküler ağrısı olan hastalarda transforaminal epidural steroid enjeksiyonu (TESE) ve darbeli radyofrekans (DRF)'ın lomber dorsal kök gangliyonuna (DKG) eşzamanlı uygulanmasının ile yalnız başına TESE tedavisi ile karşılaştıııması amaçlanmıştır.

Gereç ve Yöntem: Çalışmaya toplam 129 hasta dahil edildi. 67 hastaya TESE, 62 hastaya TESE+ DKG-DRF uygulandı. Demografik veriler, cerrahi müdahaleler ve ilaçların tipleri, işlemin yapıldığı vücut tarafı ve sayısı kaydedildi. Hastalar ameliyat öncesi ve sonrası 10. gün, birinci ve üçüncü ay takip ziyaretlerinde değerlendirildi ve Görsel Analog Skala (VAS, 0-10) ile ağrı skorları değerlendirildi. Üçüncü ay takip vizitlerinde memnuniyet değerlendirmeleri ölçüldü. Başarılı terapötik yanıt, VAS skorlarında $\% 50$ veya daha fazla oranda azalma olarak tanımlandı.

Bulgular: Her iki grupta postoperatif VAS skorları preoperatif düzeylerden anlamlı olarak düşüktü ( $p<0.001)$. Tüm takip dönemlerinde TESE+ DKG-DRF grubundaki VAS skorları TESE grubundan anlamlı olarak düşüktü $(p<0.001)$. Tüm takip vizitlerinde VAS skorlarındaki azalma oranları TESE+ DKG-DRF grubunda anlamlı olarak daha yüksekti $(p<0.001)$. Tedavi memnuniyeti düzeyleri TESE+ DKG-DRF grubunda anlamlı olarak yüksekti $(p<0.01)$.

Sonuç: Çalışmamızın bulgularına göre TESE, kronik lomber radiküler ağrısı olan hastalarda kısa-orta derecede rahatlama sağlamaktadır. Tedaviye yanıtı iyileştirmek için TESE ile aynı seansta DRF'nin eşzamanlı uygulanmasının bir seçenek olarak göz önünde bulundurulması önerilmektedir.
\end{abstract}

Anahtar sözcükler: Dorsal kök gangliyonu; lomber radiküler ağrı; darbeli radyofrekans; transforaminal epidural steroid enjeksiyonu.

'Department of Anesthesiology and Reanimation, Van Training and Research Hospital, Van, Turkey ${ }^{2}$ Department of Anesthesiology and Reanimation, Uludag University Faculty of Medicine, Bursa, Turkey

Submitted (Başvuru tarihi) 13.07.2020 Accepted after revision (Düzeltme sonrası kabul tarihi) 10.01.2021 Available online date (Online yayımlanma tarihi) 06.09.2021

Correspondence: Dr. Selcan Akesen. Uludağ Üniversitesi Tıp Fakültesi, Anesteziyoloji ve Reanimasyon Anabilim Dalı, Bursa, Turkey.

Phone: +90 - 532 - 3971716 e-mail: selcanyerebakan@hotmail.com

C) 2021 Turkish Society of Algology 


\section{Introduction}

Chronic back pain is defined as the pain that persists for 12 weeks or longer without a response to treatment procedures or the improvement of the underlying cause. Radiculopathy or radicular pain occurs when specific lumbosacral nerve roots are affected, and radicular pain develops due to the irritation of the dorsal root ganglion (DRG). Interventional techniques have an essential role in the management of subacute, chronic, persistent, and refractory pain. The most important advantage of therapeutic interventions is providing pain relief in the long term as well as ameliorating the patient's condition in the short term. ${ }^{[1]}$

Epidural steroid injections to the lumbar space can be applied through interlaminar, transforaminal, or caudal approaches. In the transforaminal approach, the needle is placed in the neural foramina of the affected segment, and this way of access is preferred due to the advantage of direct administration of medication into the anterior epidural region where the pathology is located. The mechanisms of action that was granted through the administration of corticosteroid solutions into the epidural space include an anti-inflammatory action, neural membrane stabilization, and the regulation of peripheral nociceptor excitability. The addition of local anesthetics to the injected solution eliminates existent muscle spasm, providing sympathetic blockade, and improving the root irritation which provides early pain control. ${ }^{[2]}$

It has been suggested that pulsed radiofrequency (PRF), a non-ablative novel approach maintains adequate pain control in low-temperature applications, thus introduced as an alternative and widely accepted method in pain-related interventions due to its minimal effect on tissue and implication of effective treatment. There are several recent studies on the action mechanism of PRF which focus on its role in the neuromodulatory effect by changing synaptic transmission. ${ }^{[3,4]}$

There are studies supporting that PRF is an effective and safe procedure in cervical and lumbar radicular pain, and the administration of PRF onto DRG functions through the regulation of radicular pain sensation without causing soft-tissue damage. ${ }^{[5,6]}$
However, there are a limited number of studies addressing whether the addition of the DRG-PRF approach to transforaminal epidural steroid injection (TESI) provides additional analgesia. In the present study, we aimed to analyze and compare the combined effect of the simultaneous use of DRG-PRF and TESI with TESI application alone in adult patients with chronic back pain.

\section{Material and Methods}

Following the Institutional Ethical Committee approval (No: 2016-11/11), we retrospectively reviewed the medical records of 129 patients who were admitted to the pain clinic of a university hospital between January 2014 and October 2015, and underwent TESI or combined application of TESI with DRG-PRF. The study protocol was designed and conducted according to the Declaration of Helsinki.

\section{Study Participants}

The patients who did not benefit from initial treatment attempts of chronic back pain were further evaluated. The patients with $<50 \%$ pain relief compared to the baseline level were determined as the unsuccessful treatment group and offered a combined application of TESI with DRG-PRF.

\section{Inclusion/Exclusion Criteria}

Of the patients who underwent either TESI alone or TESI plus DRG PRF, subjects above the age of 18 years with chronic pain for at least 3 months, and did not respond to conservative treatment approaches including medical and physical therapies were included in the study. Patients with bulging and protrusion in lumbar magnetic resonance imaging studies as evidence of lumbar disc herniation; with a diagnosis of spinal stenosis or underwent unsuccessful spinal surgery; with radiculopathy without a motor deficit in lower extremities were also included in the study.

Exclusion criteria included age below 18 years, acute pain symptoms, indication for lumbar disc herniation surgery, symptoms of sequestration in a lumbar disc, allergy to steroids or contrast agents, coagulation disorder, and administration of facet joint injection or intradiscal RF in addition to TESI or TESI plus DRG PRF. 


\section{Study Parameters}

The demographic variables, medical history including surgeries and medications, details of the procedure (side, application characteristics), visual analog scale (VAS) scores at the pre-operative period and on the 10 days, $1^{\text {st }}$ and $3^{\text {rd }}$ month follow-up points after the operation, number of the application, patients' satisfaction with the procedure in terms of postoperative analgesic efficacy, ability to perform daily activities, and improvement in functional capacity were also recorded according to their own responses on the $3^{\text {rd }}$-month follow-up visit interviews. More than a $50 \%$ decrease in post-operative VAS scores compared to the pre-operative period was considered as a successful outcome. In satisfaction analyses, patients who stated that the procedure was ineffective, provided poor and fair benefit, and gave a grade of 0,1 , or 2 were considered as "unsatisfied," whereas those who stated that the procedure provided good and excellent results with grades of 3 or 4 were considered as "satisfied," and the outcomes were recorded (Table 1).

\section{Procedures}

After the clearance of the eligible patients for the procedure with routine laboratory tests, patients were admitted to the hospital on the day of the application in accordance with the standard fasting procedure. Patients were informed verbally and written informed consent was obtained before the procedure. After patients were taken to the operating room, peripheral vascular access was established and patients were routinely monitored using electrocardiography, pulse oximetry, and non-invasive blood pressure. Patients were positioned in the prone position on the operating table and pre-medicated using $0.02 \mathrm{mg} / \mathrm{kg}$ IV midazolam. The lumbar region was cleansed using an iodine-based antiseptic solution and a sterile cover was applied. For the application of TESI, a C-arm fluoroscope was positioned to the anterior-posterior, and the level to be treated was identified with a radiopaque rod. The intervertebral foramen at the level of operation site was visualized by placing the $\mathrm{C}$-arm fluoroscope in an oblique position at approximately $15-20$ degrees. To provide optimal foramen patency, attention was paid to ensure that the vertebral endplates at this level were in a single line direction. If there was a superposition of the superior articular process of the underlying joint,
Table 1. Patients' satisfaction score based on analgesic activity and increased functional capacity

\begin{tabular}{lc}
\hline Score & Satisfaction \\
\hline 0 & Ineffective \\
1 & Poor \\
2 & Fair \\
3 & Good \\
4 & Excellent \\
\hline
\end{tabular}

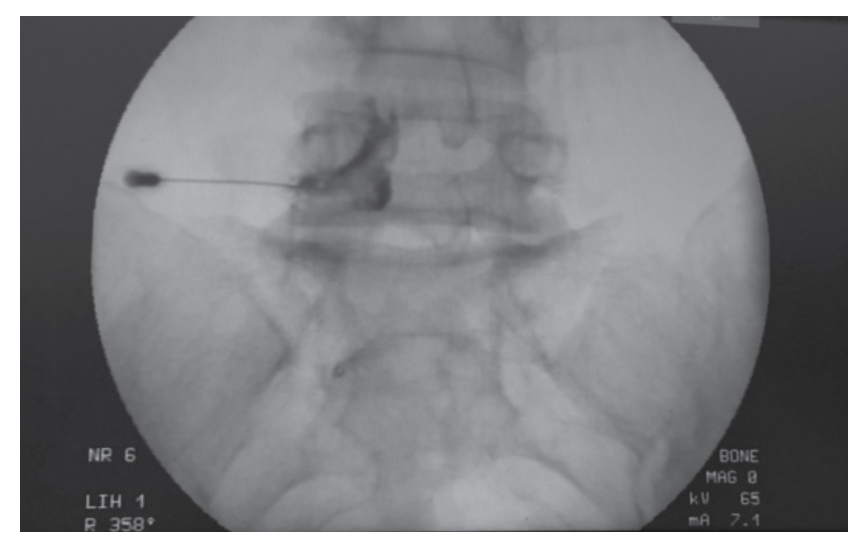

Figure 1. Spread of the contrast agent in the epidural space (anteroposterior image).

the $\mathrm{C}$-arm was rotated in the craniocaudal direction. After the application of a local anesthetic to the skin and subcutaneous region, a 25-gauge spinal needle was advanced to the intervertebral foramen. The direction of the needle was confirmed by visualization of the needle under the fluoroscope. Then, the depth of the needle tip was confirmed in the lateral image. After entering into the epidural area, the spread of the $3 \mathrm{ml}$ contrast agent (Ultravist, Schering AG. Berlin, Germany) in the anterior epidural region was visualized (Fig. 1). Any sign of arterial/venous intravasation of the contrast agent was controlled through simultaneous imaging. In case of vascular involvement, the position of the needle was changed and rechecked with additional contrast medium. After the application of the contrast medium into the anterior epidural space, the spread was confirmed by positioning the $\mathrm{C}$-arm fluoroscope to the anteriorposterior and lateral positions (Fig. 2).

While performing TESI+DRG PRF, we followed the same preparatory steps as in TESI application, and then, a 20-gauge, $10 \mathrm{~cm}$ length RF hybrid cannula with $10 \mathrm{~mm}$ active tip (Diros Technology Inc., Canada) was directed close to the DRG under the guidance of a fluoroscope. The end tip of the cannula 


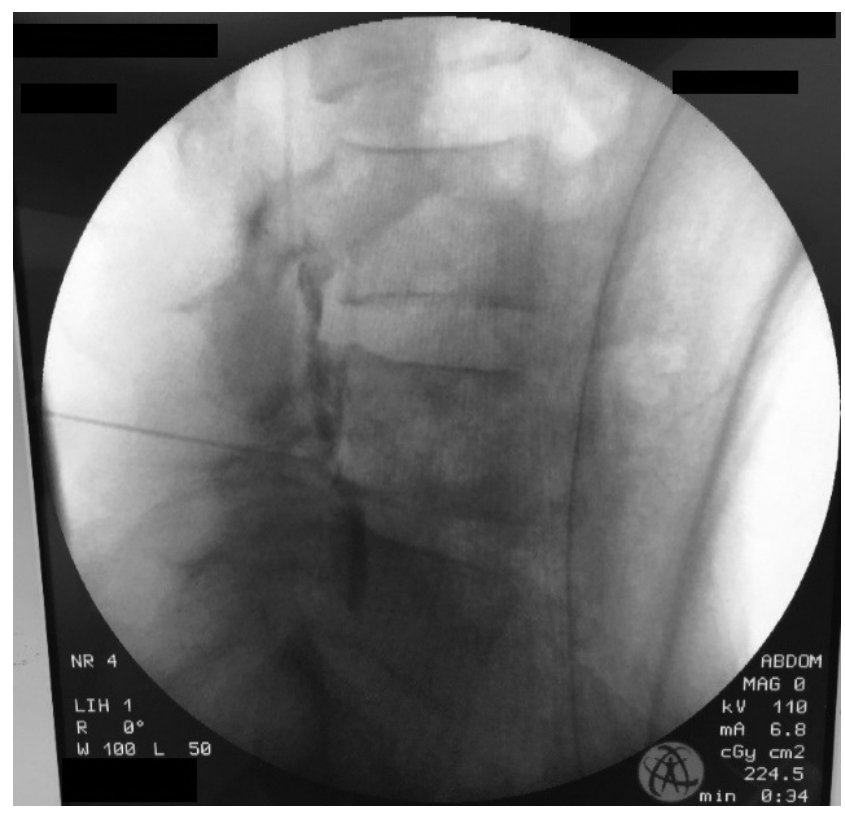

Figure 2. Spread of the contrast agent in the epidural space (lateral image).

was positioned in the lateral direction in the middle of the intervertebral foramen. When the appropriate position was achieved, the RF cannula was connected to the RF generator (Diros Technology Inc. $\mathrm{OWL}^{\circledR}$ URF-3AP, Canada). For the correct placement of the RF cannula, $50 \mathrm{~Hz}$ sensory stimulation threshold should be $\leq 0.5 \mathrm{~V}$ with a targeted impedance of $<500 \Omega$, and the patient should experience paresthesia in line with the spread of the radicular pain. After confirmation of the location of the RF cannula, a $45 \mathrm{~V}$ PRF was applied for $240 \mathrm{~s}$. During the procedure, the temperature at the electrode tip was kept under $42^{\circ} \mathrm{C}$. The RF generator was used by a medical technician in directions from the physician, and the changes stated by the patient were evaluated by the physician. After RF, the cannula slightly retreated about 2-3 $\mathrm{mm}$ to avoid an intraneural injection, and then, the electrode was removed gently.

TESI application was performed after providing a negative aspiration, and patients were given 16 mg dexamethasone $(4 \mathrm{~mL}$ ) and $10 \mathrm{mg}$ bupivacaine $(2 \mathrm{~mL})$ mixed in $2 \mathrm{ml}$ physiological saline solution. If the procedure was planned to be performed at one level, a $4 \mathrm{~mL}$ mixture was administered, while $2 \mathrm{~mL}$ of the mixture was given for each level maintaining the amount of dexamethasone stable for multiple applications.

After both procedures, patients were followed up in the recovery room for $30 \mathrm{~min}$ and taken to the pain clinic to be monitored by the nurse for the control of hemodynamic variables, early complications (a rapid increase in pain, recent neurological deficit, etc.), and evaluation of the VAS scores. Patients were discharged with medications prescribed and follow-up control visits were planned and recorded on the post-operative $10^{\text {th }}$ day and $1^{\text {st }}$ and $3^{\text {rd }}$ month time points.

\section{Statistical Analysis}

Data were analyzed using the IBM SPSS 22.0 statistical software by Uludag University Faculty of Medicine Department of Biostatistics. Descriptive statistics were stated as mean and standard deviation. The Kolmogorov-Smirnov test was used to test the normal distribution of the variables. Median with minimum/maximum values, frequency, and ratio was presented for abnormally distributed variables. Quantitative data were analyzed using the MannWhitney U-test and independent samples t-test. The paired Wilcoxon test was used for the analysis of repeated measurements. Qualitative data were analyzed using the Chi-square or Fisher's exact test. $\mathrm{P}<0.05$ was considered statistically significant.

\section{Results}

The study included 129 patients who were administered TESI or TESI+DRG PRF between January 2014 and October 2015. While 67 patients (Group 1) received TESI, 62 patients (Group 2) had TESI+DRG PRF. There was no significant difference between the TESI and TESI+DRG PRF groups regarding the age and sex distribution of patients $(p>0.05)$.

The etiologies underlying the chronic back pain are presented in Table 2. Patients were diagnosed with intervertebral disc disorder, spinal stenosis, and history of unsatisfactory spinal surgery. The distribution of diagnoses did not show a significant difference between Group 1 and Group 2 ( $p>0.05$ ).

There was no significant difference between Group 1 and Group 2 regarding the prevalence of concomitant diseases such as hypertension, hyperlipidemia, diabetes mellitus, coronary artery disease, and hypothyroidism ( $p>0.05)$. When patients with a history of intervertebral disc surgery were analyzed, no significant difference was detected between the groups ( $>0.05$ ) (Table 2). 
Table 2. The etiologies of the patients underlying chronic back pain

\begin{tabular}{|c|c|c|c|c|c|}
\hline \multirow[t]{2}{*}{ Diagnosis } & \multicolumn{2}{|c|}{ TESI } & \multicolumn{2}{|c|}{ TESI+DRG-PRF } & \multirow[t]{2}{*}{$\mathbf{p}$} \\
\hline & $\mathbf{n}$ & $\%$ & $\mathbf{n}$ & $\%$ & \\
\hline Intervertebral disc disorder & 53 & 79.1 & 50 & 80.6 & \\
\hline Spinal stenosis & 7 & 10.4 & 7 & 11.3 & 0.893 \\
\hline History of unsatisfactory spinal surgery & 7 & 10.4 & 5 & 8.1 & \\
\hline
\end{tabular}

TESI: Transforaminal epidural steroid injection; DRG: Dorsal root ganglion; PRF: Pulsed radiofrequency.

Table 3. Distribution of associated diseases and operations in Group 1 and Group 2

\begin{tabular}{|c|c|c|c|c|c|}
\hline & \multicolumn{2}{|c|}{ TESI } & \multicolumn{2}{|c|}{ TESI+DRG-PRF } & \multirow[t]{2}{*}{$\mathbf{p}$} \\
\hline & $\mathbf{n}$ & $\%$ & $\mathbf{n}$ & $\%$ & \\
\hline \multicolumn{6}{|l|}{ Associated diseases } \\
\hline No & 45 & 67.2 & 46 & 74.2 & \multirow{2}{*}{0.382} \\
\hline Yes & 22 & 32.8 & 16 & 25.8 & \\
\hline HT & 14 & 20.9 & 7 & 11.3 & 0.140 \\
\hline $\mathrm{HL}$ & 8 & 11.9 & 2 & 3.2 & 0.064 \\
\hline DM & 10 & 14.9 & 6 & 9.7 & 0.366 \\
\hline CAD & 2 & 3.0 & 4 & 6.5 & 0.350 \\
\hline Hypothyroidism & 4 & 6.0 & 5 & 8.1 & 0.641 \\
\hline \multicolumn{6}{|l|}{ Operation } \\
\hline No & 44 & 65.7 & 46 & 74.2 & \multirow{2}{*}{0.292} \\
\hline Yes & 23 & 34.3 & 16 & 25.8 & \\
\hline
\end{tabular}

TESI: Transforaminal epidural steroid injection; DRG: Dorsal root ganglion; PRF: Pulsed radiofrequency; HT: Hypertension; HL: Hyperlipidemia; DM: Diabetes mellitus; CAD: Coronary artery disease.

Patients included in the study were investigated regarding their previous medications such as gabapentin, nonsteroidal anti-inflammatory drugs, tramadol, duloxetine, and pregabalin, and no significant difference was observed between Group 1 and Group 2 regarding the ratio and type of the drugs $(p>0.05)$.

Of all the subjects in the study, 53 patients underwent a procedure for the right side, 67 on the left side, and 9 patients had a bilateral intervention. No significant difference was detected between Group 1 and Group 2 regarding the side of operation ( $p>0.05$ ) (Table 3). While the procedure was performed at a single level for 80 patients, 49 patients underwent the procedure at multiple levels. No significant difference was detected between Group 1 and Group 2 ( $p>0.05$ ). The highest number of procedures was applied to the L4-5 level. There was no significant difference between Group 1 and Group 2 regarding operation levels $(p>0.05)$ (Table 3 ).
VAS scores (0-10) during the pre-operative period and 10 days, 1 month, and 3 months after the operation were recorded. While the mean VAS score was $6.7 \pm 1.3$ in Group 1, it was $6.9 \pm 1.1$ in Group 2. The pre-operative VAS score did not show a significant difference between Group 1 and Group 2 ( $p>0.05$ ) (Table 4). Post-operative $10^{\text {th }}$ day, $1^{\text {st }}$ month, and $3^{\text {rd }}$ month VAS scores showed a significant difference as compared to the pre-operative period in both groups $(p<0.001)$ (Table 4$)$. The post-operative $10^{\text {th }}$ day, $1^{\text {st }}$ month, and $3^{\text {rd }}$ month VAS scores were significantly lower in Group 2 compared to Group 1 $(p<0.001)$ (Table 4).

The ratio of decrease in VAS scores on the postoperative $10^{\text {th }}$ day, $1^{\text {st }}$ month, and $3^{\text {rd }}$ month in the TESI+DRG PRF group was $80-88 \%$, and it was significantly higher as compared to the decrease achieved in the TESI group (44-61\%) $(p<0.001)$ (Table 4). 
Table 4. Operation sides and levels in TESI and TESI+DRG PRF groups

\begin{tabular}{|c|c|c|c|c|c|}
\hline & \multicolumn{2}{|c|}{ TESI } & \multicolumn{2}{|c|}{ TESI+DRG-PRF } & \multirow[t]{2}{*}{$\mathbf{p}$} \\
\hline & $\mathbf{n}$ & $\%$ & $\mathbf{n}$ & $\%$ & \\
\hline \multicolumn{6}{|l|}{ Side } \\
\hline Right & 30 & 44.8 & 23 & 37.1 & \multirow{3}{*}{0.349} \\
\hline Left & 31 & 46.3 & 36 & 58.1 & \\
\hline Bilateral & 6 & 9.0 & 3 & 4.8 & \\
\hline \multicolumn{6}{|l|}{ Level } \\
\hline One & 42 & 62.7 & 38 & 61.3 & \multirow{2}{*}{0.870} \\
\hline Multiple & 25 & 37.3 & 24 & 38.7 & \\
\hline L1-2 & 0 & 0.0 & 1 & 1.6 & 0.481 \\
\hline L2-3 & 2 & 3.0 & 0 & 0.0 & 0.497 \\
\hline L3-4 & 8 & 11.9 & 4 & 6.5 & 0.284 \\
\hline L4-5 & 44 & 65.7 & 47 & 75.8 & 0.207 \\
\hline L5-S1 & 36 & 53.7 & 32 & 51.6 & 0.810 \\
\hline
\end{tabular}

TESI: Transforaminal epidural steroid injection; DRG: Dorsal root ganglion; PRF: Pulsed radiofrequency.

Patients' satisfaction levels in the TESI+DRG PRF group were significantly higher as compared to the TESI group $(p<0.01)$ (Table 5).

When patients were analyzed regarding the repetition of the procedures, nine patients from the TESI group and six patients from the TESI+DRG PRF group underwent a second intervention 3 months later. Of the nine patients receiving TESI previously, three underwent TESI again, while six were given TESI+DRG PRF as the latter procedure. Of the six patients previously received TESI+DRG PRF, four patients underwent TESI and two patients underwent TESI+DRG PRF as the second procedure. No significant difference was detected between the TESI and TESI+DRG PRF groups regarding the rate of repetitive procedures $(p>0.05)$.

\section{Discussion}

Epidural steroid injections have been used for many years as an effective method for short-term pain control in patients with chronic lumbar radicular pain. Lumbar epidural steroid injection might be applied through interlaminar, transforaminal, or caudal approaches, and every clinic sets its own rules and type of choice depending on previous practices, equipment, and experience of the staff. In our clinic, the modality of choice is the transforaminal technique due to its allowance into the primary pathology area and the inflamed nerve root with a minimum effective volume.

In our study, we observed a significant decrease in pain scores compared to their baseline scores of patients diagnosed with intervertebral disc disorder, spinal stenosis, and unsuccessful spinal surgery at

Table 5. VAS scores in TESI and TESI+DRG PRF group

\begin{tabular}{|c|c|c|c|c|c|}
\hline \multirow[t]{2}{*}{ VAS } & \multicolumn{2}{|r|}{ TESI } & \multicolumn{2}{|c|}{ TESI+DRG-PRF } & \multirow[t]{2}{*}{$\mathbf{p}$} \\
\hline & Mean \pm SD & Median (Min-Max) & Mean \pm SD & Median (Min-Max) & \\
\hline Pre-operative & $6.7 \pm 1.3$ & $7(4-10)$ & $6.9 \pm 1.1$ & $7(4-9)$ & 0.130 \\
\hline Post-operative $10^{\text {th }}$ day & $3.3 \pm 2.2$ & $3(0-8)$ & $1.4 \pm 1.8$ & $0(0-6)$ & 0.000 \\
\hline$p$ value* & 0.000 & 0.000 & & & \\
\hline Post-operative $1^{\text {st }}$ month & $3.4 \pm 2.1$ & $3(0-8)$ & $2.2 \pm 1.7$ & $2(0-6)$ & 0.000 \\
\hline$p$ value* & 0.000 & 0.000 & & & \\
\hline Post-operative $3^{\text {rd }}$ month & $4.1 \pm 1.9$ & $4(0-8)$ & $2.8 \pm 1.5$ & $3(0-6)$ & 0.000 \\
\hline$p$ value* & 0.000 & 0.000 & & & \\
\hline $\begin{array}{l}\text { More than } 50 \% \text { decrease } \\
\text { in post-operative VAS score }\end{array}$ & $\mathbf{n}$ & $\%$ & $\mathbf{n}$ & $\%$ & \\
\hline Post-operative $10^{\text {th }}$ day & 41 & 61.2 & 55 & 88.7 & 0.000 \\
\hline Post-operative $1^{\text {st }}$ month & 39 & 58.2 & 55 & 88.7 & 0.000 \\
\hline Post-operative $3^{\text {rd }}$ month & 30 & 44.8 & 50 & 80.6 & 0.000 \\
\hline
\end{tabular}

TESI: Transforaminal epidural steroid injection; DRG: Dorsal root ganglion; PRF: Pulsed radiofrequency; VAS: Visual analog scale; SD: Standard deviation; Min: Minimum; Max: Maximum; ${ }^{*}$ : Variation in group compared to the pre-procedural value. 
the evaluation time points on 10 days, 1 month, and 3 months after TESI. We also observed that although TESI is an effective method in the management of lumbar radicular pain, an application of DRG-PRF in addition to TESI provided a significant improvement in pain palliation. Pain scores of the patients' receiving DRG PRF alongside TESI were lower at all evaluation time points. When patients' satisfaction considering analgesic efficacy, ability to perform daily activities, and increase in functional capacity was analyzed in the post-operative $3^{\text {rd }}$ month, the satisfaction level was observed to be significantly higher among patients receiving TESI+DRG PRF.

Ackerman et al. ${ }^{[7]}$ compared caudal, interlaminar, and transforaminal approaches in patients with L5S1 disc herniation and reported that according to their evaluations on the $2^{\text {nd }}$ week, $3^{\text {rd }}$ month, and $6^{\text {th }}$ month after the procedure, they achieved significant partial and complete pain palliation in patients who underwent the transforaminal approach. In our retrospective study investigating the pain palliation effect of TESI+DRG PRF applied in our clinic on chronic lumbar radicular pain, the number of the patients enrolled in the study was high, but the patients' diagnoses varied as intervertebral disc disorder, spinal stenosis, and inadequate or unsatisfactory outcomes following spinal surgery.

Schaufele et al ${ }^{[8]}$ compared interlaminar and TESI in their study investigating 40 patients with lumbosacral radiculopathy associated with disc herniation, where the patients were asked to assess their pain severity $1 \mathrm{~h}$ before and after the procedure, and 2-3 weeks after the procedure using the verbal numerical rating scale (VNRS). As compared to the baseline, the VNRS scores showed significant improvement in both groups at the post-operative $1^{\text {st }} \mathrm{h}$ and in the follow-up period (2-3 weeks). However, VNRS scores at 2-3 weeks were significantly lower in patients undergoing TESI than in patients undergoing interlaminar intervention.

There are a very limited number of studies addressing the effect of combining TESI with DRG-PRF in treatment success. Koh et al. ${ }^{[9]}$ conducted a randomized controlled study to evaluate the efficacy of TESI+DRG PRF in chronic refractory lumbar radicular pain due to spinal stenosis by diving pa- tients into two groups as PRF and control groups. All patients included in the study previously received TESI and their pain levels decreased for $<6$ weeks. In the experimental PRF group, three cycles of PRF were performed at $42^{\circ} \mathrm{C}$ for $120 \mathrm{~s}$ while sensory stimulation without RF lesioning was applied to the control group. Then, both groups were given steroids and local anesthetic mixture. Patients were evaluated considering NRS, Oswestry disability Index (ODI), clinical global ımpression (CGI), and drug use. At the end of the study, patients who demonstrated successful treatment results were higher in the TESI+DRG PRF group compared with the TESI group at 2 months and 3 months. In the PRF group, there was a significant improvement in the NRS and ODI scores as compared to the baseline; however, there was no significant difference between the groups regarding their average NRS, ODI, and drug use. Although this study indicated the success of treatment, no significant difference was shown between the parameters investigated. It may be due to the fact that treatment success may have not been properly evaluated. In addition, the fact that the patients included in the study had been treated with TESI and received the treatment for the $2^{\text {nd }}$ time might be the reason for the improvement in pain scores.

To avoid neural damage, high-frequency currents below $42^{\circ} \mathrm{C}$ are administered intermittently to the tissues in the PRF technique. In this way, potential side effects resulting from high temperatures are avoided. In our study population, Group 1 received only TESI and no motor or sensory stimulation was given to the RF generator whereas Group 2 was administered TESI+DRG PRF. In both Group 1 and Group 2, VAS scores showed a significant decrease at all follow-up evaluations as compared to the baseline. However, the decrease in VAS scores was significantly higher in the TESI+DRG PRF group compared with the TESI group. On the $3^{\text {rd }}$ month follow-up visits, patients were asked about their satisfaction with the procedure considering analgesic efficacy and increase in functional capacity, and it was observed that the satisfaction level of the Group 2 was significantly higher than Group 1. Our results are consistent with the increased pain palliation reported by Koh et al., ${ }^{\left[{ }^{9]}\right.}$ the only study in the literature addressing this issue. At the end of the 3-month follow-up period, 
patients in our study had a low rate of readmission for undergoing a new procedure. There was no significant difference between Group 1 and Group 2 regarding patients undergoing repeated procedures. In their review, MacVicar et al. ${ }^{[10]}$ reported $94 \%$ of treatment success in patients administered TESI with a single injection, and only $4 \%$ of the patients required more than 1 injection. Consistent with this study, our patients also applied at a lower rate for a repeat of the procedure.

Shanthanna et al. ${ }^{[11]}$ divided patients into two groups as placebo and treatment groups in their study investigating the efficacy of PRF in chronic lumbar radicular pain and applied PRF to DRG at $42^{\circ} \mathrm{C}$ for $120 \mathrm{~s}$ in the treatment group while placing a needle in DRG in the placebo group. Patients were evaluated on the $24^{\text {th }} \mathrm{h}, 4^{\text {th }}$ week, $2^{\text {nd }}$ month, and $3^{\text {rd }}$ month after treatment, and their VAS and ODI scores were recorded. The maximum difference in the VAS score was observed at $24 \mathrm{~h}$, but VAS scores did not show a significant difference between the groups at other followup periods. The improvement in the ODI score was larger at 2 and 3 months in the PRF group. In total, $31 \%$ of patients in the PRF group had experienced a more than $50 \%$ decrease in pain scores compared with $20 \%$ of patients in the placebo group. Abejon et al. ${ }^{[6]}$ investigated the analgesic efficacy of DRG PRF on chronic lumbar radicular pain in their study. They divided patients into groups depending on their diagnoses and monitored patients using the NRS and CGI scale. A 2-point decrease in the NRS score and/or a CGI score of $>5$ was considered as a successful outcome. During the 60 days of follow-up, pain scores of patients diagnosed with disc herniation and spinal stenosis significantly decreased; however, no significant change was observed in pain scores of patients with a history of unsatisfactory spinal surgery. In their randomized controlled study, Lee et al. ${ }^{[12]}$ made a comparison between TESI and PRF regarding their efficacy on spinal radicular pain secondary to disc herniation. They reported a decrease in VAS scores of both groups, but there was no statistically significant difference between the groups. These data suggest that the efficacy of both procedures diversifies depending on the underlying etiology for chronic back pain, and studies with homogenous patient groups and varied doses of the medications and number of treatment attempts might yield various results.
Recent studies suggest the application of bipolar PRF also on cervical DRG as an efficient treatment option for the management of refractory chronic cervical radicular pain. ${ }^{[13]}$ Despite the lack of certain knowledge on the mechanisms of actions of monoor bipolar PRF in management of chronic pain, some researchers suggest various effects in molecular level including decreased microglial activity, cellular damages on the sensory nociceptive axons, and triggering the noradrenergic and serotonergic pain inhibitory pathways. ${ }^{[14]}$ However, a case series reported complications with bipolar PRF such as an aggravated radicular pain that resolved after 2 weeks. Thus, the procedures involving PRF should be applied by an experienced team, and possible future complications should be thoroughly followed up, and the physicians should be aware of the possible solutions to these complications. ${ }^{[15]}$ In our study groups, we did not experience a complication during the followup period, and the satisfaction rates were favorable in both groups.

The single-center design of the study and the application of all procedures by two different experienced physicians and its retrospective characteristic may be considered as the limitations of this study. Although the patient groups were diagnosed with intervertebral disc disorder, spinal stenosis, and unsatisfactory outcome following spinal surgery, the distribution patterns of the patients within the study groups were homogeneous. As other evaluator scales on pain, functions, sleeping, and quality of life do not apply to all of the patients, and VAS is the most commonly used scale to evaluate the degree of pain in our clinic, we did not implicate another grading procedure in our study. Although there is no specific standard for the follow-up period in the literature, and long-term follow-up is essential for evaluating the success of the procedures, the 3-month follow-up period of our study may be considered relatively short. However, despite the patients' satisfaction results after the procedure, we did not further follow up on the cases after treatment, and they did not require surgery within the follow-up period.

\section{Conclusion}

According to our results, the administration of TESI in patients with chronic lumbar radicular pain is an 
effective method for providing short-term and/or mid-term pain control. A simultaneous application of DRG-PRF to the affected site with TESI should be considered in an attempt to increase patients' favorable response to treatment. There is a need for prospective double-blind, placebo-controlled randomized trials involving a higher number of patients with broader types of diagnoses to confirm and report the current and potential benefits of the applied procedures in the future.

\section{Conflict-of-interest issues regarding the authorship or article: None declared.}

\section{Peer-rewiew: Externally peer-reviewed.}

\section{References}

1. Veizi E, Hayek S. Interventional therapies for chronic low back pain. Neuromodulation 2014;17(Suppl 2):31-45. [CrossRef]

2. Erdine S. Ağrı Baskı. İstanbul: Nobel Tıp Kitabevleri; 2007.

3. Cahana A. Pulsed radiofrequency: A neurobiologic and clinical reality. Anesthesiology 2005;103(6):1311, author reply 1313-4. [CrossRef]

4. Cahana A, Van Zundert J, Macrea L, van Kleef M, Sluijter M. Pulsed radiofrequency: Current clinical and biological literature available. Pain Med 2006;7(5):411-23. [CrossRef]

5. Choi GS, Ahn SH, Cho YW, Lee DG. Long-term effect of pulsed radiofrequency on chronic cervical radicular pain refractory to repeated transforaminal epidural steroid injections. Pain Med 2012;13(3):368-75. [CrossRef]

6. Abejón D, Garcia-del-Valle S, Fuentes ML, Gómez-Arnau Jl, Reig $\mathrm{E}$, van Zundert J. Pulsed radiofrequency in lumbar radicular pain: clinical effects in various etiological groups. Pain Pract 2007;7(1):21-6. [CrossRef]
7. Ackerman WE $3^{\text {rd }}$, Ahmad M. The efficacy of lumbar epidural steroid injections in patients with lumbar disc herniations. Anesth Analg 2007;104(5):1217-22. [CrossRef]

8. Schaufele $M$, Hatch $L$, Jones $W$. Interlaminar versus transforaminal epidural injections for the treatment of symptomatic lumbar intervertebral disc herniations. Pain Physician 2006;9(4):361-6.

9. Koh W, Choi SS, Karm MH, Suh JH, Leem JG, Lee JD, et al. Treatment of chronic lumbosacral radicular pain using adjuvant pulsed radiofrequency: A randomized controlled study. Pain Med 2015;16(3):432-41. [CrossRef]

10. MacVicar J, King W, Landers M, Bogduk N. The effectiveness of lumbar transforaminal injection of steroids: A comprehensive review with systematic analysis of the published data. Pain Med 2013;14(1):14-28. [CrossRef]

11. Shanthanna H, Chan P, McChesney J, Thabane L, Paul J. Pulsed radiofrequency treatment of the lumbar dorsal root ganglion in patients with chronic lumbar radicular pain: A randomized, placebo-controlled pilot study. J Pain Res 2014;7:47-55. [CrossRef]

12. Lee DG, Ahn SH, Lee J. Comparative effectivenesses of pulsed radiofrequency and transforaminal steroid injection for radicular pain due to disc herniation: A prospective randomized trial. J Korean Med Sci 2016;31(8):1324-30. [CrossRef]

13. Yang $S$, Chang MC. Effect of bipolar pulsed radiofrequency on chronic cervical radicular pain refractory to monopolar pulsed radiofrequency. Ann Palliat Med 2020;9(2):169-74.

14. Chang MC, Cho YW, Ahn SH. Comparison between bipolar pulsed radiofrequency and monopolar pulsed radiofrequency in chronic lumbosacral radicular pain: A randomized controlled trial. Medicine (Baltimore) 2017;96(9):e6236. [CrossRef]

15. Lee DG, Cho YW, Ahn SH, Chang MC. The effect of bipolar pulsed radiofrequency treatment on chronic lumbosacral radicular pain refractory to monopolar pulsed radiofrequency treatment. Pain Physician 2018;21(2):E97-103. [CrossRef] 